\begin{tabular}{|c|c|c|c|c|c|c|}
\hline \multirow{4}{*}{ Impact Factor: } & ISRA (India) & $=3.117$ & SIS (USA) & $=0.912$ & ICV (Poland) & $=6.630$ \\
\hline & ISI (Dubai, UAE & $=0.829$ & РИНЦ (Russia & $=\mathbf{0 . 1 5 6}$ & PIF (India) & $=1.940$ \\
\hline & GIF (Australia) & $=0.564$ & ESJI (KZ) & $=8.716$ & IBI (India) & $=4.260$ \\
\hline & JIF & $=1.500$ & SJIF (Morocco & $=\mathbf{5 . 6 6 7}$ & OAJI (USA) & $=0.350$ \\
\hline
\end{tabular}

\section{SOI: 1.1/TAS DOI: 10.15863/TAS International Scientific Journal Theoretical \& Applied Science}

\author{
p-ISSN: 2308-4944 (print) e-ISSN: 2409-0085 (online) \\ Year: $2019 \quad$ Issue: $04 \quad$ Volume: 72
}

Published: $24.04 .2019 \quad$ http://T-Science.org
QR - Issue

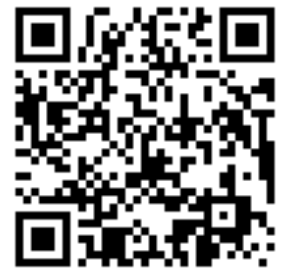

QR - Article

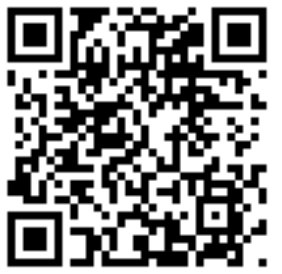

Dilfuza Daminovna Turaeva

Senior Lecturer, Russian Language teacher Department of Uzbek and Russian languages Karshi Engineering-Economic Institute

Karshi, Uzbekistan

\title{
TEACHING RUSSIAN LANGUAGE THROUGH MOODLE
}

Abstract: In today's century technology (computer, video, online-papers, animation, and webinars) is widely being utilized in teaching system. In teaching Russian language as a second language, we designed curriculum with electronic platform MOODLE for bachelor's degree program. Furthermore, having gained a lot of teaching experience in a virtual environment, the scholars showed forms of successful organization of the educational process provide tactics and strategies for studying how to use presentations, video lectures and webinars, as well as teaching aids based on the electronic platform MOODLE

This article highlights the features of MOODLE platform which enables good use of the potential of information and communication tools in the practice of teaching the Russian language for special purposes (mining engineering).

Key words: IT technologies, MOODLE, Russian language as a second language.

Language: English

Citation: Turaeva, D. D. (2019). Teaching Russian language through MOODLE. ISJ Theoretical \& Applied Science, 04 (72), 321-324.

Soi: http://s-o-i.org/1.1/TAS-04-72-37 Doi: crossef https://dx.doi.org/10.15863/TAS.2019.04.72.37

\section{Introduction}

The modern educational situation in our country is characterized by the following trends: the integration of information technologies into the educational process, constant scientific development, and the necessity for teachers to develop linguistic personality who tends to self-directed study of second language. One the modern electronic library where a teacher upload all relevant subject-specific ematerials is platform MOODLE, which has multiple features, including the ability to engage in social networking outside the traditional classroom; a wide range of technological advances and service functions such as wiki, chat, conferences, e-mail, discussions (forums), webinars, interactive and graphical chat, questionnaires, seminars, surveys, a unified registration system and users' statistical monitoring, assessment of students' performance, and feedback in the form of pedagogical interaction.

The rapid development of ICT and its wide use in the teaching of Russian not only expanded the competence of language teaching, but also led to the formation of a new trend: e-linguistics (or computer linguistics). The main purpose of e-linguistics is to provide a theoretical and practical base for language teaching in the new conditions of the information society [4]. The electronic language teaching in our study converts the spontaneous process of informatization of theory and practice of teaching Russian into a scientific system managed by teachers and linguists. Moreover, the features of electronic elearning were further studied in details.

\section{Virtual learning}

"The virtual learning environment is a unified information training field, which enables the full realization of a complex of innovative individualcentered learning technologies aimed at remote pedagogical contact, providing a high degree of student's autonomy in choosing the trajectory of learning, self-control of the chosen path of learning and that encourages self-evaluation of educational achievement [1].

In non-philological practice, Russian language proficiency for a student with technical profiles is a necessary communication tool for future professional communication. In order to solve various communication tasks in teaching and professional spheres of socializing, a student should possess the following professional competences:

$\square$ analyze and interpret professionally-oriented information contained in authentic texts and documents; 


\begin{tabular}{|c|c|c|c|c|c|c|}
\hline \multirow{4}{*}{ Impact Factor: } & ISRA (India) & $=3.117$ & SIS (USA) & $=0.912$ & ICV (Poland) & $=6.630$ \\
\hline & ISI (Dubai, UAE & $=0.829$ & РИНЦ (Russia & $=0.156$ & PIF (India) & $=1.940$ \\
\hline & GIF (Australia) & $=0.564$ & ESJI (KZ) & $=8.716$ & IBI (India) & $=4.260$ \\
\hline & JIF & $=1.500$ & SJIF (Morocco & $=\mathbf{5 . 6 6 7}$ & OAJI (USA) & $=0.350$ \\
\hline
\end{tabular}

$\square$ realize the collection, analysis and processing of data which are necessary for solving professional tasks;

$\square$ organize the activity of a small group created for the realization of a certain educational project;

$\square$ use modern technical means and information technologies etc. for solving communicative tasks [7].

The most important aspect of teaching Russian language to a student with technical profiles in Russian higher education is the development of language-communicative competence in the chosen specialty and preparation for independent professional activity in Russian [5].

It is obvious that the process of teaching Russian language, focused on the learning by students of the above competencies, is impossible without the use of modern IT tools. The use of these tools, among other things, leads the learning process in one line with the current level of technological development of society, as well as allows us to synchronize the study of Russian language as a second language with teaching professional disciplines. In this regard, we consider it expedient to speak not only about the use of ICT in teaching Russian as a second language, and more specifically the integration of ICT in teaching students the language of their specialty (mining engineering). Additionally, scientific interest in the development of communicative competence by students of nonlinguistic specialties is closely related with the understanding of the significance of creative activity of specialists in different spheres and situations concerned with cross-cultural communication, partnerships in trade, and collaborative scientific and industrial work.

\section{ICT is the mean to reflect needs of learners}

These are the following tasks for a teacher at classes of the Russian language for special purposes at a beginner stage of learning (level A1):

> To enhance language skills (reading, writing, speaking) of learners at an beginning stage

$>$ To focus on their oral production (making a dialogue, conversation between teacher and student)

$>$ To develop their comprehension of Russian language (using different videos, documentary films in A1 level)

$>$ To improve their pronunciation in Russian language (promote them reading authentic texts in A1 level, giving them education in Russian phonetics)

$>$ To promote them making a sentence (enhancing their knowledge of Russian grammar)

As the most effective forms of ICT in the educational process of teaching Russian as a second language, we developed an algorithm for the educational process to teach Russian as a second language for specific purposes based on the use of a mixed model of learning (blended learning framework). By mixed model of learning we mean the complex use of the following forms of ICT: electronic presentations in PDF format, video lecture, webinars, and tutorials developed on the electronic platform MOODLE. Often such forms of ICT are used for remote work with students in teaching practice. They are organically woven into the learning process in the classroom and extracurricular self-study in our model.

The proposed algorithm consists of the following successive steps:

$\square$ Formation of a professional thesaurus based on teaching materials developed for the electronic platform MOODLE.

$\square$ Realization of control and checking activities for the learning of professional terminology by using video lectures on professional topics in Russian.

$\square$ Securing collection and analysis skills on professional issues through the creation of presentations. Webinar.

One of the online meeting opportunity is

Webinars involve conducting online meetings or presentations via the Internet in real time, during which each participant uses his computer, and a leading person uses a voice signal and slides. Communication between actors is supported via the Internet through a loading from network or installed on the computer of each participant application[8]. The advantages of using webinars are:

- the possibility to organize a big audience simultaneously;

- the availability of information via sound and visualization delivery;

- interactive communication with the audience;

- performance of online presentations, training sessions, synchronization and activities of the leading person and the listener.

A distinctive feature of webinars is expressed in the integrative work of students, since their participation in this event involves not only getting information from material provided by peers but also its discussion, analysis and evaluation.

\section{Electronic lecture in teaching Russian language}

Video lectures typically involve lecture material outlined by the teacher as a video record, which can be represented to the student in a delayed mode. In addition to compliance with the substantive requirements applicable to the traditional classroom lecture, a video lecture must satisfy the following specifications:

- maximal simplicity and accessibility of the presentation. This requirement stems from the fact that in this case there is no interactive contact between 


\begin{tabular}{|c|c|c|c|c|c|c|}
\hline \multirow{4}{*}{ Impact Factor: } & ISRA (India) & $=3.117$ & SIS (USA) & $=0.912$ & ICV (Poland) & $=6.630$ \\
\hline & ISI (Dubai, UAE & $=0.829$ & РИНЦ (Russia & $=0.156$ & PIF (India) & $=1.940$ \\
\hline & GIF (Australia) & $=0.564$ & ESJI (KZ) & $=8.716$ & IBI (India) & $=4.260$ \\
\hline & JIF & $=1.500$ & SJIF (Morocco & $=\mathbf{5 . 6 6 7}$ & OAJI (USA) & $=0.350$ \\
\hline
\end{tabular}

the teacher and the audience. The teacher is not able to detect a lack of listeners' understanding of any part of the presented material, and students cannot tell him about it immediately;

- inclusion of a large number of accompanying (visual) material in the video lectures. Compliance with this requirement to some extent compensates for the lack of interactive contact with the audience and makes maximum use of ICT's potential. In this case, the text of the lecture is fully synchronized with the giving of accompanying material. Performance of video lecture, for example, on the topic "Pumping oil and gas", students must first watch the documentary film on pumping system and understand the content with the help of post experience in L1. Furthermore, discuss the video lecture among each others. Moreover, do exercise in order to improve and acquire technical vocabularies which were stated in the film. It must be noted that in our practice video lectures are not training activities or a checkout task, the purpose of which is to identify the student's ability to perceive by hearing the material covered on the themes of specialty. In this case, we check the amount of material on professional terminology learned by the students, which was presented in the learning process while working with textbooks.

\section{Conclusion}

Information technologies have radically changed the approach to teaching in terms of learning and digestion of knowledge and skills of students. There has been a mode delivery transformation of teachers' knowledge and skills. Electronic presentations, webinars and video lectures, tutorials, created on the electronic platform MOODLE proved their effectiveness as innovative forms of information and communication technologies in the practice of language education for the students with technical profiles. The most difficult aspect, in our opinion, is to achieve synchronization of language, speech and meaningful (professional) components in teaching Russian language to students for special purposes. This synchronization can be successfully achieved in a mixed model of learning when tasks performed using ICT, organically woven into the basic educational process, help to consolidate skills and work in the information environment based on the active use of information and communication technologies, which is very important for the formation of students' future professional competencies. In addition, the integration of ICT in teaching Russian for special purposes introduces students to innovative forms of professional verbal and nonverbal communication, which in turn contributes to rapid adaptation to the world of the future specialization. Moreover, platform MOODLE gives students more opportunities to study the languages and other subjects even if they will not participate in the classes. Platform MOODLE is the Electron library where we may download e-materials; e-books, e-videos to study the subject better in order to improve our background knowledge.

\section{References:}

1. Bogomolov, A. N. (2013). Virtualnaya sreda obucheniya: k harakteristike ponyatiya. Moscow State University Journal (Vestnik CIE MSU), 3, 28- 33.

2. Gural, S. K., \& Sorokina, E. I. (2012). Interferentnie yazikovie yavleniya i polozhitelniy perenos. Tomsk State University Journal, 354

3. Inozemceva, E. A. (2012). Vebinar sovremennaya forma distancionnogo obucheniya. Vestnik MGUPI, 39, 145 - 148.

4. Khromov, S. S. (2014). Smart-tehnologii v prepodavanii russkogo yazika kak inostrannogo. Moscow State University Journal, Seriya 19: Lingvistika i mezhkulturnaya kommunikaciya, 3, 149 - 157.

5. Levicheva, E. V. (2012). O nekotorih trebovaniyah $\mathrm{k}$ presentaciyam na seminarskih zanyatiyah v vuzovskoy praktike. Almanah sovremennoy nauki i obrazovaniya, 8 (63), 107 109.

6. Simakova E. S. (2011). Vistuplenie studentov $s$ elektronnoy presentaciei $v$ uchebno-nauchnoy sfere: problemi i zadachi obucheniya. Nauka I kultura Rossii. Materiali USH Mezhdunarodnoy nauchno-prakticheskoy konferencii, posvyashennoy Dnyu slavyanskoy pismennosti i kulturi pamyati svyatih ravnopostalnih Kirilla i Mefodiya. Samara, 26-27 maya 2011, 195 - 197.

7. Skorikova, T. P., \& Orlov E. A. (2013). Aktivizaciya poznavatelnoy deyatelnosti inostrannih magistrantov $\mathrm{v}$ uchebno-nauchnoy sfere pri ispolzovanii informacionnocomputernih tehnologiy. Izvestiya UZGU. Seriya Lingvistika i pedagogika, 1, 87 - 92. 


\begin{tabular}{|c|c|c|c|c|c|}
\hline ISRA (India) & $=3.117$ & SIS (USA) & $=0.912$ & ICV (Poland) & $=6.630$ \\
\hline ISI (Dubai, UAE & $=0.829$ & РИНЦ (Russia) & $=0.156$ & PIF (India) & $=1.940$ \\
\hline GIF (Australia) & $=0.564$ & ESJI (KZ) & $=8.716$ & IBI (India) & $=4.260$ \\
\hline JIF & $=1.500$ & SJIF (Morocco) & $=5.667$ & OAJI (USA) & $=0.350$ \\
\hline
\end{tabular}

8. Zeleneckaya, I. S., \& Gulyaeva, N. A. (2013).

Ekonomicheskiy modul. Moscow: MESI Rabochaya programma uchebnoi disciplini «Russkiy yazik kak inostranniy (inostranniy Publishing House. 